\title{
KONCEPCJA LEAN MANAGEMENT W SEKTORZE BANKOWYM
}

\author{
Marcin Grobelak, Robert Ulewicz \\ Politechnika Częstochowska \\ Wydział Zarządzania
}

\begin{abstract}
Streszczenie: W artykule przybliżono zagadnienia związane z koncepcją Lean Management, wykorzystywaną w celu zwiększenia konkurencyjności poprzez wdrażanie kultury ciągłego rozwoju, obniżenie kosztów operacyjnych, podwyższanie jakości działań na rzecz klientów. Przedstawiono badania literaturowe dotyczące szczupłego zarządzania, analizę przypadku oraz ocenę autora na temat wdrażania omawianej koncepcji w bankowości.
\end{abstract}

Słowa kluczowe: konkurencyjność, szczupłe zarządzanie, Lean Management, marnotrawstwo, bankowość

DOI: $10.17512 /$ znpcz.2018.1.23

\section{Wprowadzenie}

Obecne nieprzerwanie zmieniające się warunki gry rynkowej sprawiają, że przedsiębiorstwa poszukują możliwości uzyskania przewagi konkurencyjnej poprzez szukanie narzędzi mogących usprawnić funkcjonowanie organizacji. Współczesne tempo rozwoju gospodarczego, społecznego, a także postęp technologiczny wywierają presję na przedsiębiorstwach i zmuszają do reagowania na sygnały docierające z rynku. Chcąc móc konkurować na rynku, trzeba monitorować otoczenie i zmiany w organizacji. Jedną z proponowanych aktualnie koncepcji do wdrożenia w firmie jest Lean Management. Koncepcja ta dawniej stosowana była wyłącznie w przedsiębiorstwach produkcyjnych, obecnie ma zastosowanie praktycznie w każdym sektorze, przyczyniając się do tworzenia kultury ciągłego rozwoju.

\section{Lean Management}

Szczupłe zarządzanie to metoda, która kreuje kulturę pracy w organizacji, powodującą, że wszyscy członkowie organizacji są zainteresowani obniżką kosztów, skracaniem okresu reakcji na wymagania klientów i podnoszeniem poziomu jakości, aby spełniać potrzeby w szybko zmieniającym się otoczeniu. Koncepcja Lean jest zorientowana na eliminowanie wszelkiego marnotrawstwa (Trzcielinski, Włodarkiewicz-Klimek, Pawłowski 2013, s. 14).

Omawiana koncepcja wywodzi się $\mathrm{z}$ japońskiego konceptu odchudzonej produkcji. Zastosowana została po raz pierwszy przez właściciela koncernu Toyoty - T. Ohno wraz z E. Toyodą. Opracowali oni specyficzny system zarządza- 
nia usprawniający firmę motoryzacyjną Toyota. Wprowadzili drobne zmiany, które przełożyły się na nowy model zarządzania - system produkcyjny Toyoty (Shimokawa, Fujimoto 2011).

Lean Management jest zatem niskokosztowym podejściem do zarządzania, ukierunkowanym na eliminację marnotrawstwa i zwiększanie wartości dodanej działań (Ulewicz, Selejdak 2013, s. 7-18). Zwiększanie wartości dodanej jest realizowane przez m.in. upraszczanie wewnętrznych struktur i procedur obowiązujących we wszystkich działach przedsiębiorstwa. Może się to odbywać także przez stosowanie wybranych technik, aby produkty lub usługi były tworzone przy wykorzystaniu jak najmniejszej ilości zaangażowanych środków (Womack, Jones, Ross 2001, s. 10). Szczupłe zarządzanie wyróżnia pięć zasad, które stanowią fundament i zarazem wskazówki odnoszące się zarówno do przedsiębiorstw jako całości, jak i do poszczególnych procesów. Wspomniane pięć zasad to (Hines 2003, s. 8):

- określenie, jakie działania przynoszą wartość z perspektywy klienta;

- zidentyfikowanie szeregu czynności niezbędnych do stworzenia produktu w całym łańcuchu wartości, które pomogą znaleźć obszary marnotrawstwa;

- stworzenie nowego łańcucha wartości (Mesjasz-Lech, Skowron-Grabowska 2014, s. 421-423), wolnego od marnotrawstwa;

- robienie tego, czego wymaga klient;

- dążenie do perfekcji, usuwanie zidentyfikowanych przyczyn marnotrawstwa.

Marnotrawstwo jest stratą dla przedsiębiorstwa, natomiast straty są kosztem.

Eliminacja marnotrawstwa jest głównym założeniem koncepcji Lean pozwalającym zaoszczędzić zasoby zarówno materialne, jak i niematerialne, które byłyby przeznaczane na czynności nie tworzące wartości dodanej.

Lean Management sprawdza się obecnie zarówno w działalności produkcyjnej, w logistyce, jak i w działalności usługowej. Jednym z głównych celów wdrażania koncepcji Lean jest przystosowanie przedsiębiorstwa do warunków panujących na rynku, mając na względzie dokonywanie głębokich przekształceń i zmian w jej funkcjonowaniu (kultura organizacyjna, wyznawane wartości, misja oraz przyjęta strategia (Borkowski, Ulewicz 2011, s. 39-47)). W myśl tej koncepcji zarządzanie jest procesem ciągłym, raczej powolnym, wprowadzającym radykalne i całościowe zmiany $\mathrm{w}$ strukturze, procesach oraz postawach i zachowaniach pracowników (Łukasik, Brendzel-Skowera 2015, s. 163-164). Różnica w sposobie myślenia według koncepcji Lean w porównaniu $\mathrm{z}$ tradycyjnym sposobem postrzegania funkcjonowania organizacji jest znacząca i widoczna (Tabela 1). 
Tabela 1. Porównanie sposobów myślenia Lean oraz tradycyjnego

\begin{tabular}{|l|l|}
\hline \multicolumn{1}{|c|}{ Sposób myślenia Lean } & \multicolumn{1}{c|}{ Tradycyjny sposób myślenia } \\
\hline $\begin{array}{l}\text { Planowanie zadań i działania są określane } \\
\text { podczas dialogu z członkami organizacji. }\end{array}$ & $\begin{array}{l}\text { Plany produkcyjne oraz oczekiwana } \\
\text { wydajność są wcześniej ustalone. }\end{array}$ \\
\hline $\begin{array}{l}\text { Obniżenie kosztów następuje poprzez } \\
\text { wzrost produktywności załogi. }\end{array}$ & $\begin{array}{l}\text { Minimalizacja kosztów osiągana jest przez } \\
\text { inwestycje i automatyzację. }\end{array}$ \\
\hline $\begin{array}{l}\text { Progres można osiągnąć wyłącznie poprzez } \\
\text { dużą liczbę prostych sposobów na } \\
\text { osiągnięcie celu. }\end{array}$ & $\begin{array}{l}\text { Progres jest do osiągnięcia poprzez } \\
\text { kompleksowe rozwiązania. }\end{array}$ \\
\hline $\begin{array}{l}\text { Materiały zawierające wady są odrzucane. } \\
\text { Organizowanie oraz planowanie procesów } \\
\text { odbywa się w sposób empiryczny. }\end{array}$ & $\begin{array}{l}\text { Materiały zawierające wady są po pewnym } \\
\text { czasie naprawiane. }\end{array}$ \\
\hline $\begin{array}{l}\text { Błędy są usuwane możliwie najszybciej, } \\
\text { rozrzutność jest eliminowanana dla kierownictwa. }\end{array}$ & $\begin{array}{l}\text { Rozrzutność oraz błędy występują } \\
\text { w każdym procesie. }\end{array}$ \\
\hline $\begin{array}{l}\text { Pracownik powinien czuć się } \\
\text { odpowiedzialny za koszty. }\end{array}$ & $\begin{array}{l}\text { Pracownik z zasady nie czuje się } \\
\text { odpowiedzialny za koszty. }\end{array}$ \\
\hline
\end{tabular}

Źródło: (Mieszajikina 2012, s. 23)

Wdrażanie koncepcji Lean w miejscach o zupełnie innej filozofii pracy może być obarczone pewnym ryzykiem. Kraje Wschodu mają dość charakterystyczną kulturę, która jest podziwiana i często naśladowana. Czasami jednak te uwarunkowania sprawiają wiele problemów w Europie Zachodniej. Europejscy menedżerowie chcą widzieć natychmiastowe postępy, a widoczne i nagłe zmiany przedkładają nad preferencje japońskich zarządzających, którzy wolą postępować w sposób ciągły, doskonalić procesy krok po kroku (Liker 2005, s. 14).

Mimo różnic kulturowych wiele przedsiębiorstw w Europie Zachodniej, a także w Polsce wdraża szczupłe zarządzania w swoich organizacjach. Co istotne, mowa nie tylko o przedsiębiorstwach produkcyjnych, ale coraz częściej decydują się na ten krok firmy usługowe.

\section{Szczupłe zarządzanie w bankowości}

Identyfikacja obszarów i procesów w celu eliminowania marnotrawstwa wygląda nieco inaczej w zależności od typu działalności. W działalności usługowej, wdrażanie szczupłego zarządzania może dotyczyć m.in. działów księgowości, operacyjnych, zamówień, finansowych czy personalnych. Lean Management ma wiele narzędzi, jednak na samym początku należy zmapować proces administracyjny przez ustalenie wartości produktu, sformułowanie strumienia wartości, a także przepływu wartości. Celem procesu mapowania strumienia wartości jest zredukowanie czasu przepływu, znalezienie, a później eliminacja marnotrawstwa w procesach administracyjnych. Do tego, np. w bankowości, wykorzystywane są następujące narzędzia (Zakrzewska-Bielawska 2009, s. 86-87): 
- Standaryzacja pracy - to tworzenie, utrzymywanie i doskonalenie standardów realizacji zadań dla każdego pracownika biurowego, np. w obszarze realizacji i przetwarzania zamówień, uzupełniania dokumentów, wystawiania faktur, drukowania zestawień.

- Jakość u źródła (Poka-Yoke) - celem jest stworzenie systemu pracy biurowej pozwalającej na wczesną identyfikację błędu i uniemożliwienie przekazania go dalej. Przykładem w procesie administracyjnym mogą być: harmonogram pracy, tablice, które monitorują przebieg pracy, listy kontrolne.

- FIFO - to sposób na sprawny przepływ; określa właściwą kolejność przepływu usługi czy produktu. Kontroluje proces na wyjściu w porównaniu z wejściem.

- Organizacja stanowiska pracy (5S) - polega na właściwym przygotowaniu miejsca pracy i utrzymaniu na nim porządku, np. stosowanie przegródek z opisami czy trzymanie artykułów biurowych tam, gdzie są używane.

- Wizualna kontrola - to używanie łatwych do rozpoznania, wizualnych znaków usprawniających pracę w biurze, np. oznaczenie pomieszczeń i kierunków ruchu w celu sprawnego przemieszczania się do celu, graficzna lokalizacja poszczególnych stanowisk pracy na mapie całego biura (diagram spaghetti).

- Zaangażowanie ludzi - polega na przekazywaniu pracownikom najważniejszych informacji na temat wprowadzanej koncepcji Lean i właściwych sposobów postępowania, co wymaga konieczności ciągłego doszkalania.

- Praca zespołowa - delegowanie obowiązków i odpowiedzialności na całą grupę, co zastępuje ograniczenie bezpośredniej kontroli ze strony przełożonego na rzecz samokontroli, co z kolei zwiększa zaangażowanie u pracowników.

- Niezawodność urządzeń - polega na podjęciu działań eliminujących marnotrawstwo powiązane z kondycją i dostępnością sprzętu.

Powyższe narzędzia pozwalają na usprawnienia procesów w przedsiębiorstwie przez ograniczenie formalizacji, redukcję kosztów i zmianę kultury pracy.

G. Przebinda poddał analizie wdrożenie koncepcji Lean w trzech bankach, przedstawiając zastosowane narzędzia i sposób ich wykorzystania (Tabela 2).

Kluczową wielkością, która powinna zostać zoptymalizowana, jest czas. Zasoby ludzkie organizacji są w stanie wykonać więcej czynności przynoszących korzyść przedsiębiorstwu, jeśli dzięki właściwie wdrożonej koncepcji Lean pracownicy zwiększą swoją osobistą efektywność. Efekty wdrożenia narzędzi szczupłego zarządzania mogą poprawić efektywność procesu nawet o $75 \%$.

Ważnym obszarem pracy, na którym banki skupiają uwagę, jest zwiększenie efektywności członków organizacji, a poprzez wdrażanie narzędzi szczupłego zarządzania jest to realne w krótkim czasie. Cały proces wdrażania kultury Lean Management trwa co najmniej 2-3 lata, natomiast efekty - w postaci lepszych wyników w działalności operacyjnej - można uzyskać szybciej. 
Tabela 2. Sposób wykorzystania narzędzi Lean w wybranych bankach

\begin{tabular}{|c|c|c|c|}
\hline Narzędzie Lean & Bank BPH & Bank BZ WBK & ING Bank \\
\hline $5 S$ & $\begin{array}{l}\text { Porządek na miejscu pracy } \\
\text { w centrali banku } \\
\text { - efektywność i rotacja } \\
\text { pracowników między } \\
\text { zespołami }\end{array}$ & $\begin{array}{l}\text { Porządek na miejscu pracy } \\
\text { w centrali i oddziałach } \\
\text { (ochrona danych osobowych) }\end{array}$ & Brak danych \\
\hline $\begin{array}{l}\text { VM (Visual } \\
\text { Management) }\end{array}$ & $\begin{array}{l}\text { Tablice, które informują } \\
\text { o wynikach, wskaźnikach, } \\
\text { stopniu osiąganego celu }\end{array}$ & $\begin{array}{l}\text { Zastosowanie tablicy } \\
\text { z wynikami, różnymi } \\
\text { wskaźnikami, zmiana proce- } \\
\text { su wysyłki dokumentacji } \\
\text { z oddziału do centrali }\end{array}$ & $\begin{array}{l}\text { Biała tablica } \\
\text { - wizualizacja osiąganych } \\
\text { wyników, wskaźników, } \\
\text { obciążenia pracą }\end{array}$ \\
\hline $\begin{array}{l}\text { VSM (Value } \\
\text { Stream Mapping) }\end{array}$ & $\begin{array}{l}\text { Eliminacja marnotrawstwa } \\
\text { czasu w procesie } \\
\text { reklamacyjnym klienta, } \\
\text { zastosowanie specjalnego } \\
\text { oprogramowania }\end{array}$ & $\begin{array}{l}\text { Użycie oprogramowania } \\
\text { wspierającego różne procesy } \\
\text { w trakcie realizacji, } \\
\text { eliminowanie niepotrzebnych } \\
\text { czynności i dokumentów } \\
\text { w procesie otwierania } \\
\text { rachunków }\end{array}$ & $\begin{array}{l}\text { Ustalenie najważniejszych } \\
\text { wartości }\end{array}$ \\
\hline FIFO & $\begin{array}{l}\text { Kolejkowanie wniosków } \\
\text { klientów, zastosowanie } \\
\text { procesu kontrolowania } \\
\text { poprawności wniosków } \\
\text { (przed przekazaniem do } \\
\text { analityka) }\end{array}$ & $\begin{array}{l}\text { Obieg dokumentacji } \\
\text { kredytowej, optymalizacja } \\
\text { czasu oczekiwania przez } \\
\text { klienta }\end{array}$ & Brak danych \\
\hline Poka-Yoke & $\begin{array}{l}\text { Stworzenie procesu obiegu } \\
\text { informacji wewnętrznej } \\
\text { work-flow (WF) } \\
\text { - planowane dane } \\
\text { w ustalonych wartościach }\end{array}$ & $\begin{array}{l}\text { Usunięcie błędów we } \\
\text { wnioskach wprowadzonych } \\
\text { przez beneficjentów przez } \\
\text { serwis internetowy }\end{array}$ & $\begin{array}{l}\text { Ujednolicenie wartości } \\
\text { wpisywanych przez } \\
\text { doradców wniosków } \\
\text { kredytowych }\end{array}$ \\
\hline $\begin{array}{l}\text { Diagram } \\
\text { spaghetti }\end{array}$ & $\begin{array}{l}\text { Usprawnienie drogi obiegu } \\
\text { dokumentacji w centrali }\end{array}$ & $\begin{array}{l}\text { Usprawnienie drogi obiegu } \\
\text { dokumentacji w centrali } \\
\text { i oddziałach }\end{array}$ & Brak danych \\
\hline \multirow{2}{*}{$\begin{array}{l}\text { PDCA (planuj, } \\
\text { wykonaj, } \\
\text { sprawdzaj, działaj) }\end{array}$} & $\begin{array}{l}\text { Nieustanna kontrola } \\
\text { procesów - usprawnianie }\end{array}$ & $\begin{array}{l}\text { Nieustanna kontrola proce- } \\
\text { sów - usprawnianie }\end{array}$ & $\begin{array}{l}\text { Nieustanna kontrola } \\
\text { procesów - usprawnianie }\end{array}$ \\
\hline & \multicolumn{3}{|c|}{$\begin{array}{l}\text { Utworzenie w banku dodatkowej jednostki, która jest odpowiedzialna za usprawnianie } \\
\text { procesów }\end{array}$} \\
\hline
\end{tabular}

Źródło: (Przebinda 2015, s. 107-108)

Tabela 3. Efekty wdrożenia Lean Management w wybranych bankach

\begin{tabular}{|l|l|c|c|c|}
\hline \multicolumn{1}{|c|}{ Nazwa banku } & \multicolumn{1}{|c|}{ Obszar zmiany } & $\begin{array}{c}\text { Przed } \\
\text { wdrożeniem }\end{array}$ & Po wdrożeniu & $\begin{array}{c}\text { Skrócenie } \\
\text { czasu o: }\end{array}$ \\
\hline Bank BPH & $\begin{array}{l}\text { Czas poświęcony na obsługę } \\
\text { reklamacji klienta }\end{array}$ & 3 dni & 1 dzień & $67 \%$ \\
\cline { 2 - 5 } & $\begin{array}{l}\text { Ilość wygenerowanych stron } \\
\text { umowy w kontekście nowego } \\
\text { rachunku bankowego }\end{array}$ & 14 stron & 5 stron & $65 \%$ \\
\hline Bank BZ WBK & $\begin{array}{l}\text { Analiza wniosku kredytowego } \\
\text { klientów biznesowych }\end{array}$ & 5 dni & 2 dni & $60 \%$ \\
\cline { 2 - 5 } & Skanowanie dokumentacji klienta & 6 dni & 2 dni & $67 \%$ \\
\cline { 2 - 5 } & $\begin{array}{l}\text { Otwieranie rachunku bankowego } \\
\text { w oddziale banku }\end{array}$ & 40 minut & 10 minut & $75 \%$ \\
\hline
\end{tabular}

Źródło: (Przebinda 2015, s. 109) 
Niezwykle istotną rolę we wdrażaniu omawianej koncepcji pełnią zasoby ludzkie organizacji. W związku ze znaczącymi zmianami w codziennej pracy i zdarzającymi się trudnościami w przekonaniu pracowników do koncepcji szczupłego zarządzania banki najczęściej korzystają z usług firm zewnętrznych, które stopniowo wdrażają narzędzia Lean Management u swoich klientów.

\section{Studium przypadku - Raiffeisen Bank Polska}

Niniejszą analizę przeprowadzono na podstawie artykułu opublikowanego w raporcie „Inteligentna Firma 2011” (www.leanpassion.org.pl).

Dla dużej części polskich banków segment małych i średnich przedsiębiorstw stanowi strategiczną grupę klientów. O wyborze banku czy konkretnego produktu w szczególności decyduje czas, jaki upływa od złożenia wniosku do decyzji kredytowej, i czas do wypłaty środków. Dobre wyniki w tej kategorii stanowią jedno z podstawowych źródeł przewagi konkurencyjnej w segmencie instytucji finansowych obsługujących sektor małych i średnich przedsiębiorstw.

Efektywna optymalizacja procesów ma sens przede wszystkim wtedy, gdy prowadzi do lepszego spełniania oczekiwań klientów, a jednocześnie wspiera realizację strategii firmy. Dobrym przykładem usprawnienia jest projekt optymalizacji procesu kredytowego zgodnie z założeniami koncepcji Lean Management dla klientów MŚP przeprowadzony w Raiffeisen Bank Polska.

Cały proces optymalizacji został podzielony na trzy kroki: analiza stanu obecnego (2 miesiące), projekt pilotażowy obejmujący dwa regiony (9 miesięcy) oraz roll out na cały kraj (6 miesięcy).

Analizując stan obecny, na początku próbowano na nowo zidentyfikować potrzeby i oczekiwania klientów, zrozumieć, czego dokładnie spodziewają się odbiorcy, w jaki sposób i jak szybko chcą otrzymywać produkt. Kolejne działania polegały na zidentyfikowaniu celów strategicznych i odpowiedzi na pytanie, czy dany proces w najlepszy możliwy sposób zaspokaja potrzeby klientów i przyczynia się do realizacji strategii organizacji. Powiązanie celów strategicznych z projektami usprawniającymi procesy jest kluczowym warunkiem powodzenia wszelkich optymalizacji. Badanie procesu rozpoczęto od „mapowania strumienia wartości”. Narzędzie to pozwala na obserwowanie przebiegu całego procesu przy uwzględnieniu wszystkich wykonywanych czynności i dostarczanych informacji, a także sił oraz środków, które z punktu widzenia klienta i strategii organizacji nie wnoszą żadnej wartości. Na tym etapie zidentyfikowano również najczęściej występujące problemy na poszczególnych etapach procesu. Następnie zespół, w skład którego weszli specjaliści reprezentujący działy sprzedaży, ryzyka, wyceny nieruchomości, back office, pisania umów, uruchomienia i obsługi posprzedażowej, opracował tzw. mapę strumienia wartości stanu przyszłego. W celu weryfikacji modelu działania przeprowadzono projekt pilotażowy $\mathrm{w}$ dwóch regionach, zrealizowany przez zespół przeszkolony w zakresie szczupłego zarządzania.

Projekt pilotażowy był związany z przygotowaniem projektu, czyli zbudowaniem planu komunikacji dla wszystkich etapów projektu uwzględniającego grupy docelowe odbiorców, szkolenie uczestników projektu z metodologii Lean 
Management, następnie budowanie wzajemnych celów, czyli kaskadowanie celów strategicznych do najniższego poziomu w organizacji, oraz ustalenie czynników sukcesu, wskaźników KPI i poziomów do realizacji. Kolejnym krokiem była maksymalizacja jakości wniosków kredytowych, gdyż jakość przekazywanych dokumentów powodowała zwroty, zapasy i kolejki, a tym samym mocno wpływała na wydłużenie procesu kredytowego. W trakcie projektu pilotażowego wdrożono także tablice wizualizacyjne, które przyczyniły się do stworzenia przejrzystego środowiska do zarządzania, w którym cele, standardy oraz wyniki są łatwo dostępne i widoczne dla wszystkich.

Ostatnim krokiem było wdrożenie w środowisku pilotażowym w oparciu o PDCA (plan, do, check, act) nowego standardu obsługi dla wszystkich regionów. $\mathrm{Na}$ początku przeprowadzono analizę stanu obecnego w pozostałych regionach, nieobjętych badaniem pilotażowym. Następnie przygotowano liderów do pełnienia nowej roli w organizacji (program coachingowy Lean Leadership) oraz przekazano im wiedzę dotyczącą standardów procesowania (na podstawie pilotażu) z odpowiedzialnością za nowy proces.

Efektem projektu w Raiffeisen Bank Polska była poprawa efektywności procesu kredytowego w sektorze małych i średnich przedsiębiorstw. Czterokrotnie zwiększono odsetek transakcji spełniających oczekiwania klientów w zakresie czasu do decyzji i wypłaty. Bardzo istotne było także rozpoczęcie budowania kultury Lean w organizacji nastawionej na spełnienie oczekiwań klienta w najbardziej efektywny sposób.

\section{Badanie wlasne}

W ramach badań własnych zostało przeprowadzone studium przypadku wdrożenia Lean w jednym z banków funkcjonujących w Polsce. Wywiad ekspercki został przeprowadzony $\mathrm{z}$ liderem Lean $\mathrm{w}$ województwie śląskim. Lean lider to osoba dobrze znająca narzędzia Lean oraz monitorująca efekty stosowania tej koncepcji. Kompetencje lidera Lean pozwalają szybko dostrzegać potencjały oraz sprawnie zarządzać projektami usprawniającymi.

Do wdrożenia koncepcji Lean została zatrudniona firma zewnętrzna, która przez pierwszy rok miała za zadanie wykształcić liderów Lean, wyznaczonych wcześniej przez pracodawcę (bank). Poza tym zadaniem firmy zewnętrznej, specjalizującej się we wdrażaniu koncepcji Lean w środowisku pozaprodukcyjnym było wprowadzenie do codzienności pracowników wybranych czynności związanych ze szczupłym zarządzaniem.

Pierwszy krok stanowiło monitorowanie wykonywanych czynności (poprzez używanie specjalistycznego oprogramowania), aby móc zweryfikować, na co pracownicy poświęcają swój czas, oraz zidentyfikować obszary wymagające poprawy. Kolejnym wdrażanym elementem było wprowadzenie dziennych spotkań przy tablicy wizualizacyjnej. Na spotkaniach były omawiane bieżące problemy zespołu. Dzięki otwartości podczas spotkań dziennych reszta zespołu mogła się uczyć na błędach innych pracowników. 
Kolejnym krokiem było wprowadzenie spotkań pt. „Rozwiązywanie ważnych problemów", które odbywały się co tydzień i trwały półtorej godziny. Na każdym spotkaniu ustalany był wspólnie temat oraz wyznaczany był prowadzący (członek zespołu).

Lean w omawianym banku funkcjonuje już dwa lata. Po roku Lean liderzy przejęli obowiązki konsultantów firmy zewnętrznej i organizacja musiała monitorować sposób korzystania z narzędzi Lean bez pomocy zewnętrznej.

Lean lider wskazał problemy, które są obecne po dwóch latach funkcjonowania koncepcji Lean w organizacji. Spotkania początkowo były traktowane jako sposób na dodatkową integrację pracowników (codzienna wymiana doświadczeń) oraz wspólne rozwiązywanie problemów. W okresach, w których nie było codziennych problemów, spotkania te były uważane przez pracowników za niepotrzebną stratę czasu. Wymóg zebrania się o wyznaczonej godzinie, a następnie brak problemów i zakończenie spotkania po dwóch minutach dla części pracowników wydawał się bezsensowny. Kolejnym zidentyfikowanym problemem był problem z wybraniem tematów przewodnich na spotkanie pt. „Rozwiązywanie ważnych problemów”. Niektóre z tematów były analizowane kilkukrotnie, ze względu na fakt, iż pracownicy mieli ograniczoną liczbę obsługiwanych procesów. Trudno było wymyślić tematy spotkań, które wnosiłyby do organizacji dużą wartość każdego tygodnia. Pracownicy, często ze względu na strach i brak umiejętności przywódczych, bali się prowadzić spotkania wiodące do dużych usprawnień.

W opinii Lean lidera zdecydowanym sukcesem, przewyższającym znacznie wymienione wyżej problemy było prowadzenie dzienników zadań/usprawnień. Pozwalały one na monitorowanie każdej czynności wykonywanej w ramach danego usprawnienia (wykreowanego podczas spotkań dzięki burzy mózgów). Każde zadanie w dzienniku ma swój status, osobę odpowiedzialną za wykonanie, planowaną datę ukończenia zadania, szczegółowy opis problemu itp. Przed wdrożeniem Lean było dużo zadań, które „umykały”, nie zostały zapisane, czasem tylko zostały zgłoszone do kierownika albo omawiane w mniejszym gronie (kilkuosobowym zespole). Obecnie nie ma takich sytuacji, zadania nigdzie nie „giną”, są zestawione w jednym miejscu i monitorowane przez lidera Lean.

Podsumowując, można powiedzieć, że wdrożenie kultury Lean nie jest zadaniem prostym, często budzi sprzeciw pracowników jako rzecz nowa, wcześniej niespotykana, dodatkowy obowiązek. Jednak w dłuższej perspektywie faktycznie eliminuje marnotrawstwo, znacznie zwiększa ilość wniosków racjonalizatorskich i drobnych usprawnień w codziennej pracy.

\section{Podsumowanie i ocena koncepcji Lean}

Koncepcja Lean Management zyskuje bez wątpienia coraz większą popularność zarówno na świecie, jak i w Polsce. Na stronach internetowych polskich firm specjalizujących się we wdrażaniu koncepcji Lean można zauważyć wiele korporacji, dużych firm z zagranicznym kapitałem, które są przedstawiane w sekcji „Nasi dotychczasowi klienci”, co oznacza stosowanie narzędzi Lean w praktyce. 
Można stwierdzić, że popularność tej koncepcji wynika z rezultatów, jakie przynosi przedsiębiorstwom decydującym się na wdrożenie elementów szczupłego zarządzania. Strategia w oparciu o Lean Management wydaje się być zdroworozsądkowym założeniem ze względu na to, iż skupia się na eliminowaniu strat, niepotrzebnie wykonywanych czynności, unikaniu marnotrawstwa zarówno czasu, jak i zasobów.

To maksymalne wyszczuplenie przedsiębiorstwa nie jest górnolotną ideą, ale koncepcją, która przynosi konkretne, mierzalne rezultaty, zwiększając tym samym konkurencyjność przedsiębiorstwa. Mimo iż metoda Lean stanowi źródło tak dużych korzyści, nie wszystkie przedsiębiorstwa decydują się na jej wdrażanie.

Implementacja szczupłego zarządzania nie jest procesem prostym do przeprowadzenia dla osób wdrażających. Nie jest też łatwe zrozumienie sensu tej koncepcji dla pracowników przedsiębiorstwa. W przypadku pracowników biurowych, administracyjnych w celu dostrzeżenia wykonywania niepotrzebnych czynności, aby eliminować straty, bardzo często stosowanym narzędziem jest rejestracja każdej czynności, jaką wykonuje pracownik, za pomocą systemu informatycznego, którzy mierzy czas poświęcony na poszczególne czynności. Co zrozumiałe - dla pracownika, który do tej pory nie musiał tego robić, jest to obowiązek zwykle bardzo frustrujący, wykonywany niechętnie i często z dużym oporem. Nawet w przypadku dobrych rezultatów osiąganych przez firmę, lepszych wskaźników wyznaczonych przez wprowadzających Lean do firmy dobrze jest zwrócić uwagę na wskaźnik fluktuacji pracowników. Przy okazji zmian związanych z wdrożeniem omawianej koncepcji istnieje możliwość utraty pracowników, którzy cenią sobie wykonywanie obowiązków bez presji monitorowania każdej czynności, którą w danej chwili wykonują.

Podsumowując, należy pamiętać, że metody Lean nie można w przedsiębiorstwie narzucić, warto natomiast przedstawić argumenty mówiące o korzyściach nie tylko dla firmy, ale także dla pracowników. Trzeba też nadmienić, że efekty poprawionego procesu może być widać bardzo szybko, natomiast wdrożenie koncepcji Lean w całej firmie to proces długotrwały. Bardzo przydatny do prawidłowego wdrożenia Lean jest zespół zewnętrzny specjalizujący się we wdrażaniu strategii Lean. Pomoże on uniknąć lub wesprze w zmniejszeniu negatywnych skutków, takich jak np. stres pracowników i spadek motywacji.

\section{Literatura}

1. Borkowski S., Ulewicz R. (2011), Quality as Part of the Mission of the Company, [w:] Nove trendy $v$ manazerstve kvality. 4. rocnik medzinarodneho vedeckeho seminara. 12-13 aprila. Trnava, Trnawa, s. 39-47.

2. Hines P. (2003), Kierunek - organizacja LEAN, Wydawnictwo LeanQ Centrum, Gdańsk.

3. Liker J.K. (2005), Droga Toyoty: 14 zasad zarzadzania wiodacej firmy produkcyjnej świata, MT Biznes, Warszawa.

4. Łukasik K., Brendzel-Skowera K. (2015), Wykorzystanie wspótczesnych koncepcji zarzadzania w ustugach - studium przypadku, [w:] Gostkowska-Dźwig E., Mrozik M. (red.), Wyzwania i perspektywy przedsiębiorczej organizacji. Konkurencja, innowacja, koncepcja zarządzania, Wydawnictwo Wydziału Zarządzania Politechniki Częstochowskiej, Częstochowa, s. $162-171$. 
5. Mesjasz-Lech A., Skowron-Grabowska B. (2014), Application of Information Technology in Supply Chain Management as Exemplified by Companies in Poland, [w:] Jaki A., Rojek T. (eds.), Managing Organizations in Changing Environment. Models - Concepts - Mechanisms, Foundation of the Cracov University of Economics, Kraków, s. 417-425.

6. Mieszajikina E. (red.) (2012), Przedsiębiorczość w zarządzaniu i socjologii, Wydawnictwo Wyższej Szkoły Przedsiębiorczości i Administracji w Lublinie, Lublin.

7. Przebinda G. (2015), Narzędzia Lean w ustugach bankowych, Acta Univeritatis Nicolai Copernici, Wydawnictwo Uniwersytetu Mikołaja Kopernika w Toruniu, Torun.

8. Shimokawa K., Fujimoto T. (red.) (2011), Lean Management. Narodziny systemu zarzadzania. Rozmowy z Taiichi Ohno, Eiji Toyoda i innymi osobami, które kształtowaty system zarzadzania w Toyocie, Lean Enterprice Institute Polska, Wrocław.

9. Trzcieliński S., Włodarkiewicz-Klimek H., Pawłowski K. (2013), Współczesne koncepcje zarządzania, Wydawnictwo Politechniki Poznańskiej, Poznań.

10. Ulewicz R., Selejdak J. (2013), Wplyw koncepcji Lean Manufacturing na bezpieczeństwo pracy, [w:] Tabor J. (red.), Zarzadzanie bezpieczeństwem i higiena pracy. Wspótczesne problemy bezpieczeństwa pracy, Wydawnictwo Wydziału Zarządzania Politechniki Częstochowskiej, Częstochowa, s. 7-18.

11. Womack J.P., Jones D.T., Ross D. (2001), The Machine that Changed World: The Story of Lean Production, Harper Collins, New York.

12. www.leanpassion.org.pl (dostęp: 08.09.2016).

13. Zakrzewska-Bielawska A. (2009), Wybrane aspekty zastosowania koncepcji Lean Management $w$ procesach administracyjnych przedsiębiorstwa, [w:] Czekaj J. (red.), Metody zarządzania procesami $w$ świetle studiów i badań empirycznych, Studia i Prace Uniwersytetu Ekonomicznego w Krakowie, Kraków, s. 83-92.

\section{THE CONCEPT OF LEAN MANAGEMENT IN THE BANKING SECTOR}

Abstract: This article presents issues related to the concept of lean management used in order to increase competitiveness through implementing a culture of continuous development, reducing operating costs, improving the quality of activities for customers. The article presents an overview of publications on lean management, a case study and author's assessment of the implementation of the discussed concept in the banking sector.

Keywords: competitiveness, lean management, waste, banking 